\title{
Expression and function of the insulin receptor substrate proteins in
}

\section{cancer}

\author{
Katerina Mardilovich, Shannon L Pankratz and Leslie M Shaw*
}

Address: Department of Cancer Biology, University of Massachusetts Medical School, Worcester, Massachusetts 01605, USA

Email: Katerina Mardilovich - katerina.mardilovich@umassmed.edu; Shannon L Pankratz - shannon.pankratz@umassmed.edu; Leslie M Shaw* - leslie.shaw@umassmed.edu

* Corresponding author

Published: 17 June 2009

Cell Communication and Signaling 2009, 7:14 doi:10.1 I86/I478-8IIX-7-14

This article is available from: http://www.biosignaling.com/content/7////4

(C) 2009 Mardilovich et al; licensee BioMed Central Ltd.

This is an Open Access article distributed under the terms of the Creative Commons Attribution License (http://creativecommons.org/licenses/by/2.0), which permits unrestricted use, distribution, and reproduction in any medium, provided the original work is properly cited.

\begin{abstract}
The Insulin Receptor Substrate (IRS) proteins are cytoplasmic adaptor proteins that function as essential signaling intermediates downstream of activated cell surface receptors, many of which have been implicated in cancer. The IRS proteins do not contain any intrinsic kinase activity, but rather serve as scaffolds to organize signaling complexes and initiate intracellular signaling pathways. As common intermediates of multiple receptors that can influence tumor progression, the IRS proteins are positioned to play a pivotal role in regulating the response of tumor cells to many different microenvironmental stimuli. Limited studies on IRS expression in human tumors and studies on IRS function in human tumor cell lines and in mouse models have provided clues to the potential function of these adaptor proteins in human cancer. A general theme arises from these studies; IRS-I and IRS-4 are most often associated with tumor growth and proliferation and IRS-2 is most often associated with tumor motility and invasion. In this review, we discuss the mechanisms by which IRS expression and function are regulated and how the IRS proteins contribute to tumor initiation and progression.
\end{abstract}

\section{Introduction}

The Insulin Receptor Substrate (IRS) proteins are a family of cytoplasmic adaptor proteins that were first identified for their role in insulin signaling. The first family member to be identified, IRS-1, was initially characterized as a 185 $\mathrm{kD}$ phosphoprotein that was detected in anti-phosphotyrosine immunoblots in response to insulin stimulation [1]. IRS-2 was discovered as an alternative insulin receptor substrate, initially named 4PS, in insulin-stimulated cells derived from Irs- $1 \%$ mice [2]. IRS-1 and IRS-2 are ubiquitously expressed and are the primary mediators of insulindependent mitogenesis and regulation of glucose metabolism in most cell types (reviewed in [3]). Humans express one additional family member, IRS-4, which is more restricted in its expression pattern and is found pri- marily in brain, kidney, thymus and liver [4]. A fourth IRS protein, Irs-3, is expressed in rodents, but not in humans $[5,6]$. More distantly related IRS family members IRS-5 and IRS-6, also known as DOK4 and DOK5, share homology in their N-termini, but have truncated C-termini [7-9] (Figure 1). Despite their significant homology, it is clear from the genotypes of knockout mice that the IRS proteins have non-redundant normal functions. Irs-1\% mice are born small and remain runted throughout their lives, implicating a role for this IRS protein in somatic growth regulation $[10,11]$. A similar contribution of the IRS homolog Chico to the regulation of cell size and growth in Drosophila has been observed [12]. Mice deficient for Irs-1 develop insulin resistance but do not progress to diabetes because they maintain normal pancreatic $\beta$-cell 


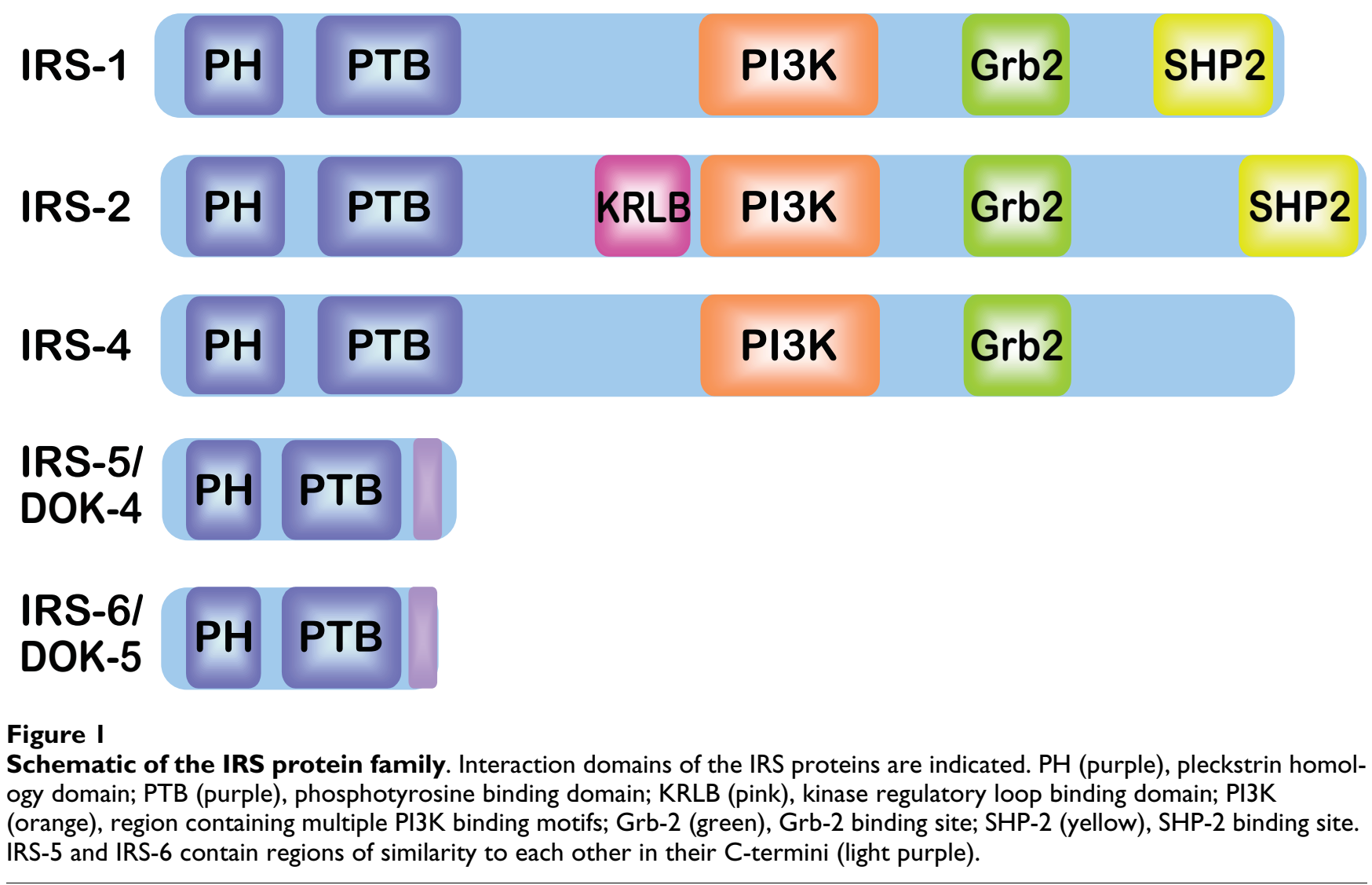

numbers. Irs-2\% mice are normal in size but have brain defects, the result of a $50 \%$ decrease in neuronal proliferation $[13,14]$. In contrast to Irs-1\% mice, Irs-2-deficient mice develop early-onset diabetes due to a combination of peripheral insulin resistance and a loss of $\beta$-cell function $[13,15]$. Irs- $2 \%$ females are also infertile, which together with evidence from insulin-signaling in Drosophila and C. elegans, supports a conserved mechanism for integrating reproduction and metabolism [16]. Irs-4\% mice are phenotypically normal, with only mild growth, reproductive and insulin sensitivity defects [17]. These differences in IRS function in normal development and physiology are also evident in cancer.

The IRS proteins contain no intrinsic enzymatic activity and they contribute to signaling through their function as adaptors to organize signaling complexes [18]. They share their highest level of homology in their N-termini, which contain two highly conserved domains that contribute to their recruitment to activated upstream receptors. The first of these domains is the pleckstrin homology (PH) domain. The PH domain is hypothesized to mediate both protein-protein interactions that facilitate the recruitment of the IRS proteins to receptors, and protein-phospholipid interactions that localize the IRS proteins to the cell membrane, in close proximity to transmembrane receptors
[19-21]. The second conserved region is the phosphotyrosine binding (PTB) domain, which interacts with NPXY motifs in activated receptors $[22,23]$. An additional motif that contributes to receptor recruitment, the kinase regulatory loop binding (KRLB) domain, has been identified only in IRS-2 (Fig. 1)[22,24]. Upon binding to upstream receptors, the IRS proteins are phosphorylated on tyrosine residues in their C-termini, generating binding sites that recruit downstream effectors $[25,26]$. Effectors that have been characterized to bind to the IRS proteins include PI3K, Grb-2, SHP-2, Fyn, c-Crk, CrkII and Nck [9,27-32]. A recent study that utilized phosphorylated bait peptides to profile all potential phosphotyrosine dependent interaction sites in IRS- 1 and IRS-2 identified additional potential interacting proteins [33]. However, additional studies will be necessary to determine if these effectors are recruited to the intact IRS proteins in response to physiological stimuli. It is the combined action of the downstream effectors that determine the signals that are transmitted through the IRS proteins and the cellular response that occurs (Figure 2). Importantly, many of these effector-signaling pathways have been implicated in tumorigenesis and cancer progression. 


\section{Expression of the IRS proteins in human cancer}

There are relatively few reports on the expression patterns of the IRS adaptor proteins in human tumors, either at the mRNA or protein level. The majority of these studies have evaluated the expression of IRS-1 and IRS-2, which are the more ubiquitously expressed family members in normal tissue. As an overall summary, IRS expression is most often elevated in human tumors when compared with normal tissue (Table 1). Expression of both IRS-1 and IRS2 is reported to be increased in hepatocellular, pancreatic and prostate cancer and malignant pleural mesothelioma [34-40]. In other cancers, including breast, ovarian and medulloblastoma, only IRS-1 expression has been evaluated and a similar trend toward increased expression in primary tumors has been reported [41-44]. However, in breast cancer, which has been studied the most exten-

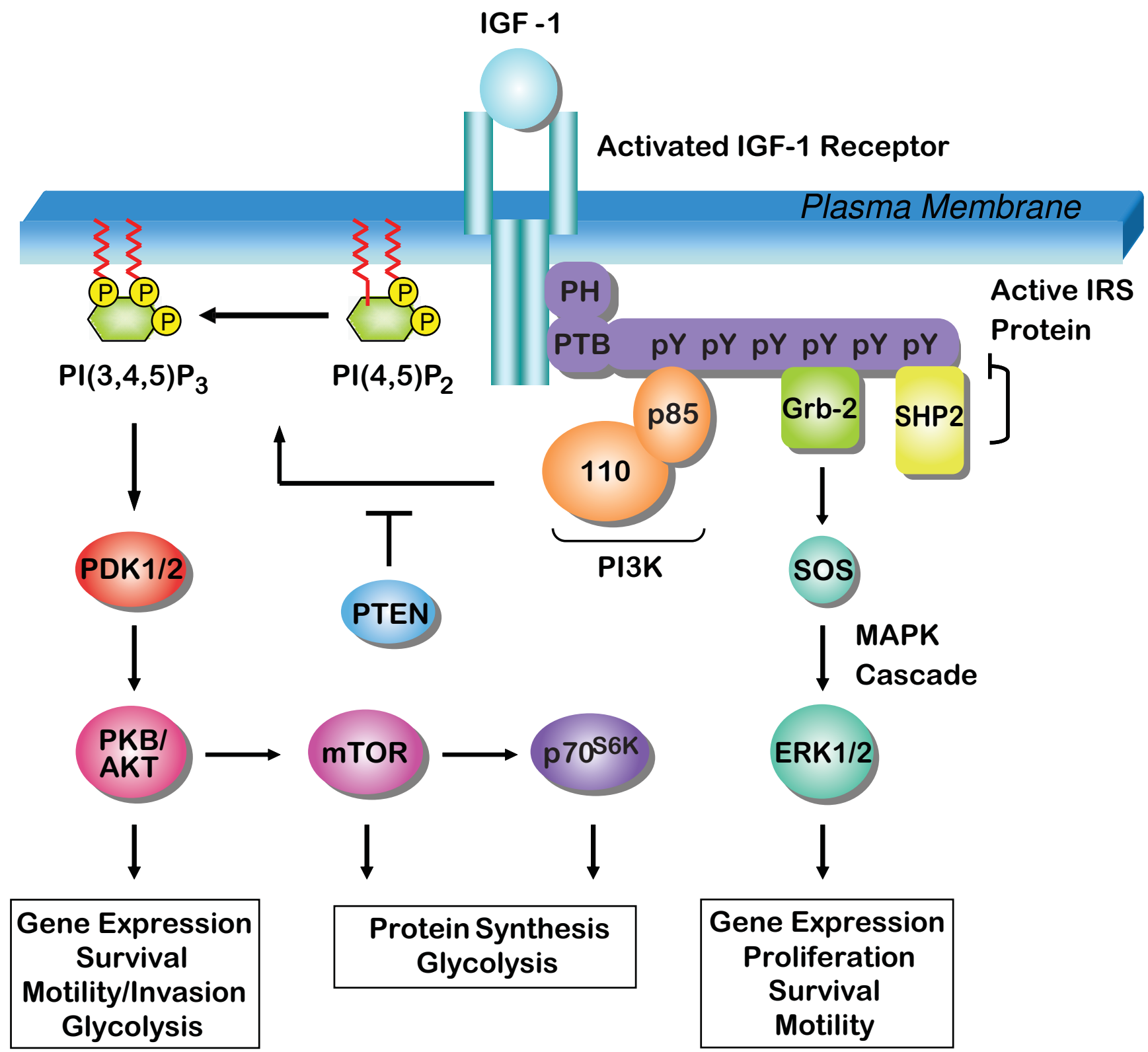

\section{Figure 2}

Signaling via the IRS proteins. The IRS proteins are recruited to activated cell surface receptors via PH/PTB domains in their $\mathrm{N}$-termini. Once bound, they are phosphorylated on tyrosine residues in their C-termini. The phosphorylation of tyrosine residues $(p Y)$ creates docking sites for the recruitment of downstream signaling effectors. Subsequently, signaling cascades are activated that can regulate gene expression, protein synthesis, glycolysis, cell proliferation, survival and motility/invasion. 
Table I: IRS expression in human cancer

\begin{tabular}{|c|c|c|c|}
\hline Cancer Type & $\begin{array}{l}\text { IRS } \\
\text { Expression }\end{array}$ & Notes & Ref(s) \\
\hline \multirow[t]{3}{*}{ Breast } & $\uparrow$ IRS-I & Well differentiated primary tumors & {$[41,43]$} \\
\hline & $\uparrow$ IRS-I & Nuclear IRS-I correlates with good prognosis & [46] \\
\hline & $\downarrow$ IRS-I & Poorly differentiated, high grade tumors & {$[45,46]$} \\
\hline \multirow[t]{3}{*}{ Hepatocellular } & $\uparrow$ IRS-I & mRNA/protein increased in $\mathrm{HCC}$ & {$[38,39]$} \\
\hline & $\uparrow$ IRS-2 & $\mathrm{mRNA} /$ protein increased in $\mathrm{HCC}$ & {$[38,39]$} \\
\hline & $\uparrow$ IRS-4 & mRNA increased in $\mathrm{HCC}$ & [39] \\
\hline Lung & $\downarrow$ IRS-I & Larger (stage IB) tumors, squamous cell carcinoma & {$[47]$} \\
\hline Medulloblastoma & $\uparrow$ IRS-I & Co-localized with polyoma JCV T-antigen in nucleus & {$[42]$} \\
\hline \multirow[t]{2}{*}{ Mesothelioma } & $\uparrow$ IRS-I & mRNA increased in malignant pleural mesothelioma & [37] \\
\hline & $\uparrow$ IRS-2 & mRNA increased in malignant pleural mesothelioma & {$[37]$} \\
\hline Ovarian & $\uparrow$ IRS-I & Protein increased in malignant epithelial tumors & {$[44]$} \\
\hline \multirow[t]{2}{*}{ Pancreatic } & $\uparrow$ IRS-I & mRNA increased in $7 / 16$ tumors & [34] \\
\hline & $\uparrow$ IRS-2 & mRNA/protein increased in ductal-like cancer cells & [35] \\
\hline \multirow[t]{2}{*}{ Prostate } & $\uparrow$ IRS-I & Protein increased in tumors and metastases & {$[36]$} \\
\hline & $\uparrow$ IRS-2 & Protein correlates with increased Myc expression & {$[40]$} \\
\hline \multirow[t]{2}{*}{ Renal } & $\uparrow$ IRS-2 & mRNA increased in clear cell carcinomas & {$[48]$} \\
\hline & $\uparrow$ IRS-5 & mRNA increased in clear cell carcinomas & [48] \\
\hline
\end{tabular}

sively of all cancers for IRS expression, there is also evidence that the expression of IRS-1 could correlate negatively with tumor progression. Specifically, IRS-1 is expressed at moderate to strong levels in normal tissue and well-differentiated carcinomas, but expression decreases in more poorly differentiated, higher-grade tumors [45,46]. Decreased IRS-1 expression is also observed in some non-small cell lung cancers (NSCLC), and this lower expression occurs more frequently in squamous cell carcinomas [47]. The conclusion drawn from the lung cancer study was that downregulation of IRS-1 may be an early event in NSCLC development. To date, the only study to examine IRS- 4 expression in human cancer reported increased expression in hepatocellular carcinoma [39]. Finally, both IRS- 2 and IRS-5 are upregulated at the level of gene expression in clear cell renal cell carcinoma [48]. One caveat to all of these expression studies, however, is that the IRS proteins can be phosphorylated on serine residues through negative feedback loops, which inhibits their function (reviewed in [49]). Therefore, expression of the IRS proteins may not reflect the functional status of these adaptor proteins. Additional studies are needed to establish clearly the expression and function of the IRS proteins in human cancer and to determine if their relative expression levels have prognostic or predictive value.

\section{Upstream receptors implicated in cancer}

The IRS proteins function as essential signaling intermediates downstream of many cell surface receptors that have been implicated in cancer. For example, the IRS proteins are major downstream effectors of the Insulin-Like Growth Factor-1 (IGF-1) receptor (IGF-1R) and they play a critical role in determining the cellular response to IGF1 stimulation [50]. There is a strong correlation between enhanced IGF-1-mediated signaling and a wide range of cancers including malignancies of the breast, colon, prostate, thyroid, liver, pancreas and central nervous system [51]. In breast cancer, IGF-1 expression is elevated in the serum of patients and the IGF-1R is frequently overexpressed and is a prognostic indicator of tumor recurrence and reduced patient survival $[52,53]$. Other growth factor/hormone receptors that signal through the IRS proteins and that are associated with cancer include the insulin, prolactin, growth hormone $(\mathrm{GH})$, and vascular endothelial growth factor (VEGF; KDR) receptors [54-56]. The IRS proteins have also been implicated in signaling downstream of the EGF receptor (EGFR), which may involve an EGFR/IGF-1R cross-talk $[57,58]$. Some integrin adhesion receptors also utilize the IRS proteins as signaling intermediates to relay intracellular signals [59-61]. In addition to surface receptors, several oncogenic fusion proteins that arise as the result of chromosomal transloca- 
tions have also been reported to signal through the IRS adaptor proteins for their tumor promoting functions. These include the ETV6-NTRK3 gene fusion found in pediatric spindle cell sarcomas and secretory breast cancer, the RET-PTC3 gene fusion found in papillary thyroid cancer and the NPM-ALK gene fusion that is a transforming oncogene found in anaplastic large-cell lymphoma [62-64]. Full length anaplastic lymphoma kinase (ALK), a member of the insulin receptor superfamily and receptor for the growth factor pleiotrophin, also signals through the IRS proteins. ALK is expressed in breast and pancreatic carcinomas, melanoma and neuroblastoma, and has been demonstrated to be rate limiting for glioblastoma growth [65]. As common intermediates of many receptors that can influence tumor progression, the IRS proteins are positioned to play a key role in regulating the response of tumor cells to microenvironmental stimuli. As a result, they are also attractive candidates to be targets for interfering with the tumor-promoting signals that are initiated through these disparate receptors.

\section{IRS function in cancer}

There are many studies on IRS function in human tumor cell lines and in mouse models that provide clues to the potential function of these adaptor proteins in human cancer. A general theme arises from these studies; IRS-1 and IRS-4 are most often associated with tumor growth and proliferation and IRS- 2 is most often associated with tumor motility and invasion.

\section{IRS-I}

IRS-1 involvement in regulating tumor cell proliferation was foreshadowed by its role in somatic growth regulation. IRS- 1 null mice are approximately $30 \%$ smaller than wildtype littermates and they maintain their runted phenotype throughout life $[10,11]$. IRS- 1 is the predominant IRS family member that is activated by IGF- 1 in well-differentiated estrogen receptor positive (ER+) human breast carcinoma cell lines [66,67]. IRS-1 mediates IGF-1dependent growth in these cells, which has also been observed for hepatocellular and prostate carcinoma, medulloblastoma and malignant pleural mesothelioma cell lines [37,66-70]. The activation of both MAPK and PI3K signaling pathways has been implicated in the stimulation of proliferation by IRS-1 $[67,69,71,72]$. IRS-1dependent signals also contribute to tumor cell survival. Suppression of IRS-1 expression by siRNA promotes apoptosis and renders ER+ breast carcinoma cells more sensitive to tamoxifen-stimulated cell death, whereas overexpression of IRS-1 confers resistance to TGF- $\beta$ induced cell death in hepatocellular carcinoma cells $[73,74]$. In contrast, Irs- $1 \%$ mammary tumor cells derived from mouse mammary tumor virus (MMTV)-polyoma virus middle $\mathrm{T}$ antigen (PyV-MT) mice are more resistant to apoptosis in response to serum deprivation than wildtype cells [75].

Transgenic mouse models have provided important information regarding IRS-1 function in cancer. Overexpression of IRS-1 in the mouse mammary gland results in mammary hyperplasia and tumorigenesis, which correlates with constitutive tyrosine phosphorylation of IRS-1, activation of Akt and Erk1/2 and association with $\beta$-catenin [76]. In mouse hepatocytes, overexpression of IRS-1 increases DNA synthesis and hepatic mass by $25 \%$, further supporting the connection between IRS-1 and proliferation [77]. However, liver tumors do not develop in these transgenic mice, possibly because Fas-receptor is upregulated and this pro-apoptotic signal balances the progrowth signals from IRS-1 [78]. The different results of these transgenic models with regard to tumorigenesis suggest that the oncogenic potential of IRS-1 may be dependent upon cellular context. Although IRS-1 overexpression promotes tumorigenesis, IRS-1 is not required for primary tumor growth as demonstrated by the fact that mammary tumor initiation and growth are not prevented or delayed in Irs-1\% mice in response to the PyV-MT antigen when compared with tumors that develop in wildtype littermates [79]. One important caveat to the IRS overexpression and knockout mouse mammary tumor studies is that the tumors that develop in both models are ER- and a possible preferential role for IRS-1 in ER+ tumor growth, which is suggested from the studies on human breast carcinoma cell lines, cannot be excluded. In contrast with the positive role for IRS-1 in early tumor development and growth, IRS-1 may play a suppressive role in tumor progression. Specifically, PyV-MT:Irs-1\% mammary tumors have a greater incidence and rate of lung metastasis when compared with $P \gamma V-M T: W T$ tumors $[79,80]$. Together with the IRS-1 expression data in human breast and lung cancer, these results reveal that loss of IRS- 1 expression or function may facilitate tumor progression [45-47]. Once again, however, it is likely that IRS-1 function is cell context-dependent because deletion of Irs-1 in $\mathrm{Apc}^{\mathrm{min}-1}$ $+(\operatorname{Min}) / \beta$-catenin-derived intestinal tumors decreases tumor incidence and growth and increases irradiationinduced apoptosis in the intestinal crypt [81].

\section{IRS-2}

The association of IRS- 2 with tumor progression was first indicated by the finding that inhibition of the IGF-1R in ER- breast carcinoma cells, which express IRS-2 and lack or have decreased IRS-1 expression, does not inhibit tumor proliferation. However, inhibition of IGF-1R function does prevent metastasis of these cells in xenograft models $[82,83]$. Several studies have since demonstrated that IGF-1 promotes cell motility and invasion in human breast carcinoma cell lines and mouse mammary tumor cells that signal preferentially through IRS-2, but not in 
cell lines that express only IRS-1 [70,84-86]. A similar role for IRS-2-dependent signaling in cell motility and invasion has been reported for neuroblastoma and mesothelioma cells $[37,87]$. In contrast to IRS-2, IRS-1 may suppress cell migration because expression of IRS-1 in LnCAP prostate carcinoma cells decreases their motility. One possible mechanism by which IRS- 2 contributes to tumor progression and cell invasion is by positively regulating aerobic glycolysis via the enhanced localization of the GLUT-1 glucose transporter on the tumor cell surface [88]. Similar to IRS-1, IRS-2 has also been implicated in promoting tumor cell survival, which is likely to contribute to its role in tumor progression. Irs-2-deficient PyV-MT-derived mammary tumor cells are significantly more sensitive to serum deprivation-induced apoptosis than wildtype tumor cells, and Irs-2\% tumors also have a higher in situ level of apoptosis [75]. Suppression of IRS-2 expression in hepatocellular carcinoma cells that express high levels of this adaptor protein also results in apoptosis [38]. Recent studies in pancreatic adenocarcinoma cells reveal that IRS2 can regulate the expression of the IGF-1R to sustain high levels of IGF-1-dependent signaling [89]. Therefore, IRS-2 may promote tumor progression by stimulating a positive feedback loop to enhance IGF-1 signaling.

Additional support for IRS-2 as a positive regulator of tumor progression comes from in vivo mouse model studies. Mammary tumor metastasis is significantly diminished in PyV-MT:Irs- $2 \%$ mice, and Irs-1 deficient tumors that express elevated levels of active (i.e. tyrosine phosphorylated) Irs-2 have enhanced metastatic rates $[75,79]$. Irs-2 expression is elevated in tumors that arise in PTEN + / - mice, and deletion of Irs-2 has no impact on tumor initiation, but it does suppress tumor growth and progression to invasive disease [40]. IRS-2, like IRS-1, can promote tumor initiation and progression when this adaptor protein is overexpressed in the mammary gland, a finding that would appear to conflict with the inability of IRS- 2 to regulate tumor proliferation in human breast carcinoma cell lines $[70,76]$. One possible explanation for this discrepancy is that functions that are not observed at normal expression levels are gained when IRS expression levels are elevated. Alternatively, IRS- 1 and IRS- 2 may contribute to early tumorigenesis through distinct mechanisms. That is, IRS-1 may promote enhanced proliferation, whereas IRS-2 may promote enhanced survival, with the common outcome being tumorigenesis and progression.

The differential abilities of IRS- 1 and IRS- 2 to promote proliferation and motility/invasion, respectively, raises the question of how these similar proteins regulate divergent functions. IRS- 1 and IRS- 2 share approximately $35 \%$ identity in their C-termini where they recruit downstream effectors to phosphotyrosine binding motifs to initiate their signaling cascades. Many of the motifs are conserved between the two family members, and IRS- 1 and IRS-2 have been reported to activate common signaling pathways including PI3K and the Erk1/2 MAPK kinases in a variety of cancer model systems $[29,60,69,90,91]$. Both of these signaling pathways have been implicated in promoting tumor cell proliferation, invasion and survival, but they cannot explain the differential abilities of IRS- 1 and IRS-2 to regulate these functions. One potential mechanism for IRS-specific regulation of tumor cell functions is the recruitment of effectors to unique binding motifs in the C-termini of the IRS proteins that activate signaling pathways selectively downstream of either IRS- 1 or IRS- 2 . For example, Rho-kinase (ROCK), which regulates cell adhesion and motility, is reported to be activated downstream of IRS-2 [91]. A recent proteomic analysis of potential IRS-1 and IRS-2 interacting partners provides further evidence that unique effectors can interact with each adaptor protein [33]. Distinct intracellular compartmentalization of IRS-1 and IRS-2 or differential sensitivities of IRS-1 and IRS-2 to negative feedback regulation would also impact the signaling outcomes of these adaptor proteins $[49,92]$. Additionally, acetylation positively regulates tyrosine phosphorylation of IRS-1 and negatively regulates tyrosine phosphoryaltion of IRS-2, which demonstrates that the function of these adaptor proteins can be differentially regulated by post-translational modifications [93-95].

An alternative mechanism for the differential involvement of IRS-1 and IRS- 2 in cancer that would allow for the activation of a common signaling pathway by these adaptor proteins was revealed during the analysis of $\operatorname{Irs} 1 \%$ mammary tumors. Akt and mTor activation were enhanced significantly in Irs $1 \%$ mammary tumors when compared with the level of activation in wildtype tumors [79]. Although signaling through IRS-1 can activate these pathways in response to insulin or IGF-1 in many other model systems, when Irs- 2 expression and function were compared between Irs $1 \%$ and WT tumors, Irs-2 activity was significantly higher in the absence of Irs-1, a finding that is mimicked by transient suppression of Irs-1 by siRNA in vitro [79]. A corresponding upregulation of Irs-1 expression and function is not observed in Irs-2\%tumors, or when Irs-2 expression is suppressed by siRNA (S. Pankratz, personal observation). Importantly, suppression of Irs-2 expression in Irs 1\%- tumor cells restores mTor activation to wildtype levels, confirming the contribution of Irs2 to the increased mTor activity [79]. These in vitro findings support the hypothesis that Irs-2 compensates for the loss of Irs-1, and in doing so, enhances the activation of signaling pathways that promote tumor metastasis. A similar compensatory upregulation of Irs- 2 expression in Irs$1 \%$ mouse embryo fibroblasts has been hypothesized to explain the dominant role that IRS-2 plays in metabolic regulation [96]. 


\section{IRS-4}

IRS-4 expression increases in response to partial hepatectomy, a liver regeneration model, and expression is higher in hepatocellular tumors when compared with normal liver tissue $[39,97]$. In HepG2 hepatocellular carcinoma cells, suppression of IRS-4 expression by siRNA decreases IGF-1-dependent proliferation, which correlates with reduced Erk and p70S6-kinase activation [98]. Irs-4 has also been implicated in the insulin-dependent proliferation of a murine T-cell lymphoma cell line and it is overexpressed in a pediatric T-cell acute lymphoblastic leukaemia (T-ALL) that harbors a breakpoint fusion between the T-cell receptor beta locus and the IRS-4 gene $[99,100]$. These studies suggest that IRS-4 functions more similarly to IRS- 1 than IRS- 2 in cancer in that it is associated with tumor proliferation.

\section{Regulation of IRS expression}

The evidence supporting the contribution of the IRS proteins to both tumor initiation and progression highlights the importance of understanding how the expression of these adaptor proteins is regulated. The differential expression patterns of the IRS proteins in both normal tissues and tumors support that their expression is likely regulated by unique mechanisms. Both the IRS-1 and IRS-2 genes are hormone-responsive, with IRS-1 regulated by the ER and IRS-2 regulated by the progesterone receptor (PR). Estrogen upregulates IRS-1 in ER+ breast carcinoma cells and IRS- 1 expression decreases in response to the ER antagonists tamoxifen and ICI 182,780 [101-104]. This inhibition of IRS-1 expression may contribute to the suppression of breast cancer by these antiestrogens [101,102]. Progestin stimulation prior to IGF-1 treatment of PR+ breast carcinoma cells upregulates IRS-2 expression levels and tyrosine phosphorylation, thereby enhancing downstream IRS-2-dependent signals [105-107].

Non-hormone-dependent pathways also regulate the IRS genes. E-box elements in the IRS-1 promoter and proteins that bind to these elements positively regulate IRS-1 expression in HepG2 hepatocellular carcinoma cells [108]. E-boxes are often found in promoters of genes involved in metabolism and are consensus cis-elements for members of the basic helix-loop-helix family of transcription factors. IRS-2 is positively regulated by the cAMP-mediated activation of CREB, a pathway that is essential for the expression of this adaptor protein in pancreatic $\beta$-cells [109]. Members of the Forkhead transcription family, including FOXO1 and FOXO3a, can also positively regulate IRS-2 expression [110]. Several growth factor/hormone signaling pathways that are associated with cancer including fibroblast growth factor (FGF), epidermal growth factor (EGF) and insulin can modulate IRS-1 and IRS-2 expression levels [86,111-113]. The EGFinduced upregulation of IRS-2 expression occurs through a JNK/c-Jun/AP-1 pathway [86]. IRS-1 expression is negatively regulated by all-trans retinoic acid (ATRA), which arrests the growth of ovarian carcinoma cells in $G_{0}-G_{1}$ [44].

Amplified in breast cancer 1 (AIB1), also known as steroid receptor coactivator-3 (SRC-3), regulates both IRS-1 and IRS-2 expression $[114,115]$. AIB1 is an oncogene that is often overexpressed in human tumors and it promotes the growth of hormone-insensitive tumor cells through its action as a coactivator of nuclear receptors [116]. AIB1 directly regulates IRS- 1 transcription by cooperating with the AP-1 transcription factor [115]. The importance of this IRS-1 regulatory pathway is demonstrated by the fact that deletion of AIB1 has a protective effect on mouse mammary glands against carcinogen-induced tumorigenesis, which can be explained in part by decreased IRS-1 expression and decreased Akt signaling [117]. The breast cancerassociated gene-1 (BRCA1) is a tumor suppressor that is mutated or deleted in $10 \%$ of hereditary breast cancers [118]. BRCA1 interacts directly with the IRS-1 promoter and inhibits transcription of the IRS-1 gene through epigenetic modification of histone $\mathrm{H} 3$ and H4 [119]. Deletion of BRCA1 in mice leads to increased expression of some members of the IGF-1 signaling pathway, including IRS-1 [119]. The association of IRS-1 expression with BRCA1 provides additional support for the involvement of this IRS family member in tumor initiation.

At the post-transcriptional level, two microRNAs, miR126 and miR-145, have been identified that target and suppress IRS-1 protein expression [120-122]. Both miR126 and miR-145 inhibit cell growth and their expression is frequently decreased in many cancer types $[120,121,123,124]$. Taken together, these findings are in keeping with a growth-promoting role for IRS-1 in tumors. miR-145 has also been implicated in positively regulating embryonic stem cell differentiation [125]. Interestingly, IRS-1 promotes stem cell self-renewal and its expression decreases during embryonic stem cell differentiation when miR-145 expression increases [126]. To date, miRNAs that target other IRS family members have not been identified.

\section{Feedback regulation of IRS function and expression}

The expression and function of the IRS proteins can be regulated post-translationally. Negative feedback regulation of the IRS proteins by serine phosphorylation was first demonstrated in insulin-dependent signaling, and this feedback pathway is essential for regulating insulin sensitivity and glucose homeostasis by limiting the magnitude and duration of the insulin signaling response [49,127-129]. Serine phosphorylation of the IRS proteins interferes with their function by targeting these adaptor proteins for inactivation and/or proteasomal degradation 
(Figure 3) [49]. Phosphorylation on specific residues, such as serines 302 and 307, disrupts IRS-1 function by inhibiting interactions between the IRS-1 PTB domain and upstream receptors $[130,131]$. As a result, IRS- 1 is not phosphorylated on tyrosine residues and cannot organize downstream signaling complexes [130,132]. IRS-1 and IRS-2 have also been shown to interact with 14-3-3 proteins through phosphoserine residues within the PTB domain [133]. Binding of 14-3-3 proteins to the PTB domain may physically prevent the IRS proteins from interacting with upstream receptors, which prevents IRSmediated signaling.

Serine phosphorylation of the IRS proteins can also directly interfere with interactions with downstream effectors and selectively prevent their activation $[131,134]$. For

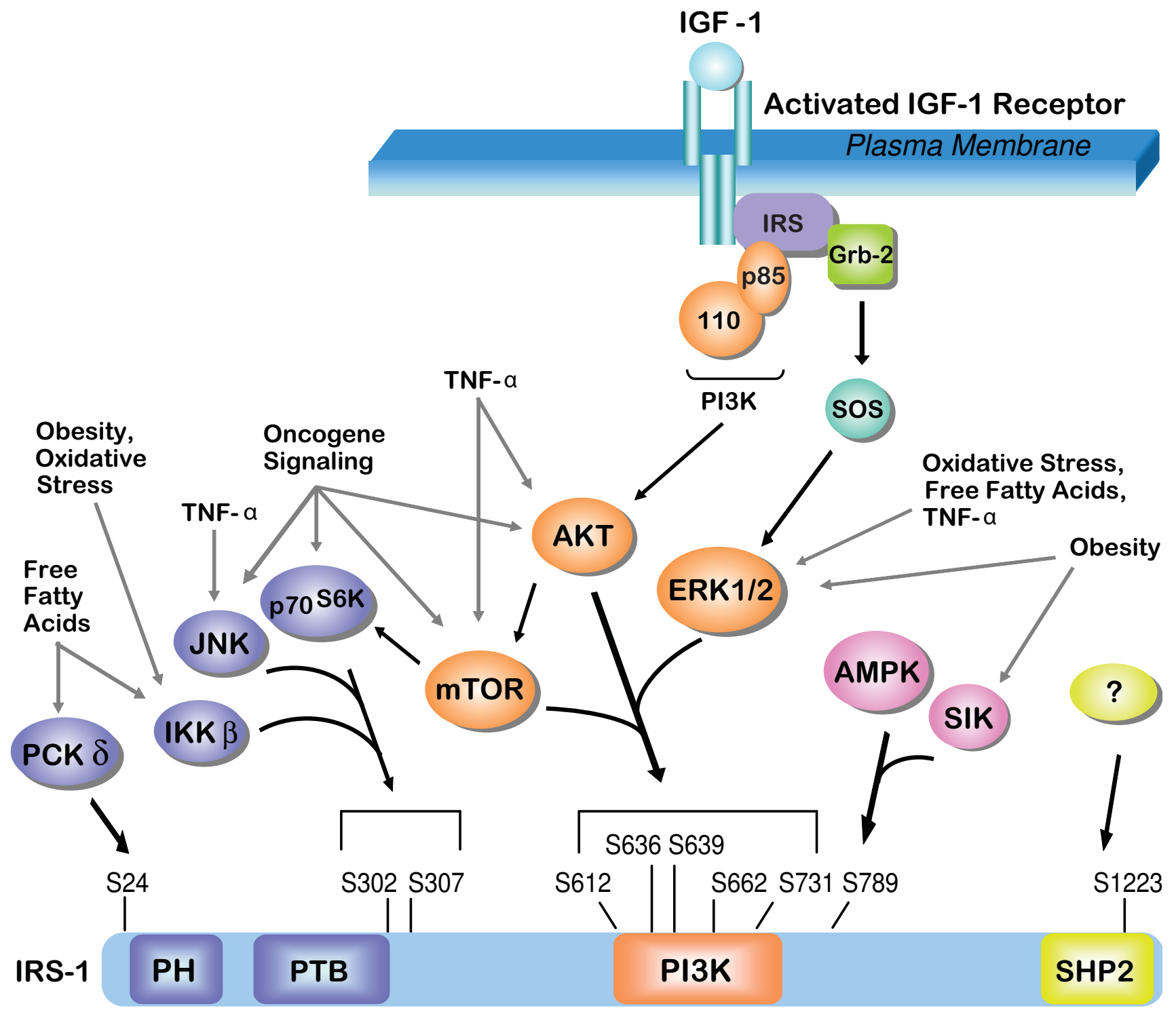

Figure 3

Negative feedback regulation of IRS-I. Serine residues that are phosphorylated in IRS-I and the kinases that target these sites are indicated. Kinases shown in purple mediate signaling events that impede IRS-I localization to the membrane or upstream receptors by disrupting PH and/or PTB domain function. Kinases shown in orange mediate signaling events that interfere with PI3K recruitment and activation. Kinases shown in pink mediate signaling events that result in phosphorylation of S789. Kinases that initiate signaling events that result in phosphorylation of SI 223 and interfere with SHP-2 binding are unknown (yellow). Exogenous stimuli that have been implicated in cancer and that can activate kinases to regulate IRS-I serine phosphorylation are indicated. 
example, phosphorylation of serine residues within the PI3K-binding region can inhibit interactions between the IRS proteins and p85, the regulatory subunit of PI3K [135]. In metastatic mouse mammary tumors, Irs-1 is phosphorylated on serine residues in the PI3K binding region and the association with p85 is decreased when compared with non-metastatic tumors [79]. Phosphorylation of serine-1223 in IRS-1 interferes with recruitment of the tyrosine phosphatase SHP-2 and, as a result, IRS-1 tyrosine phosphorylation is enhanced [136]. As mentioned previously, the distinct functions of IRS- 1 and IRS2 in tumor progression may reflect a differential sensitivity of IRS-1 and IRS- 2 to the effects of negative feedback regulation, which could alter the longevity and intensity of signals initiated through each adaptor protein $[112,137,138]$.

In addition to disrupting protein-protein interactions, serine phosphorylation of IRS-1 and IRS-2 can target these adaptor proteins for ubiquitination and degradation via the 26S proteasome [139-141]. This downregulation is mediated by an mTOR-dependent negative feedback loop that also involves p70S6-kinase [134,142-145]. In an extreme example of this negative feedback, tumors with constitutive activation of mTOR, such as those with mutations in the TSC-1 or TSC-2 genes, are benign and rarely progress to a more malignant state because both IRS- 1 and IRS-2 are degraded and cannot sufficiently activate survival signals $[143,144,146]$. mTOR can also regulate proteasome-dependent degradation of the IRS proteins by stimulating the endoplasmic reticulum stress (ER-stress) response. Loss of TSC function and subsequent mTORC1 activation lead to ER-stress and activation of the unfolded protein response (UPR) [147]. Inhibition of ER-stress in TSC- $1 \%$ or TSC- $2 \%$ cells that have decreased expression of IRS-1 and IRS-2 results in increased IRS protein stability and insulin-induced tyrosine-phosphorylation, which leads to enhanced Akt activation. Likewise, induction of ER-stress dramatically increases IRS-1 ubiquitinationdependent proteasomal degradation [147].

A significant amount of research has focused on understanding the contribution of IRS serine phosphorylation to insulin resistance and diabetes and the information gained from these studies can be applied to cancer (reviewed in [49]) (Figure 3). For example, the inflammatory cytokine tumor necrosis factor- $\alpha$ (TNF- $\alpha$ ) inactivates IRS-1 through a JNK-mediated phosphorylation of S307 (S312 in human IRS-1), which results in insulin resistance $[127,131]$. Inflammatory cells in the tumor microenvironment secrete TNF- $\alpha$ and other cytokines that positively contribute to tumor progression. Therefore, serine phosphorylation of the IRS proteins may be a mechanism by which the stromal microenvironment influences tumor behavior [148]. Additional exogenous factors that can reg- ulate IRS serine phosphorylation levels and that are associated with cancer progression include elevated free fatty acids, obesity and oxidative stress [149-152]. Potential intrinsic mechanisms to phosphorylate and regulate IRS function include many kinases that are activated by oncogenic signaling, including mTor, Akt, multiple PKC family members, Erk1/2, S6-kinase, IKK $\beta$, AMPK and SIK, as well as the aforementioned JNK $[49,153]$. Additional studies are warranted to determine the potential of these IRS feedback pathways as therapeutic targets for cancer treatment.

IRS signaling functions can be influenced by additional post-translational modifications including O-linked glycosylation and, as mentioned previously, acetylation. Increased activation of the hexosamine pathway (HBP) can induce O-glycosylation of IRS-1 and IRS-2, which decreases IRS tyrosine-phosphorylation and prevents activation of the PI3K signaling pathway $[154,155]$. Acetylation of IRS-1 and IRS-2 decreases or increases, respectively, their level of tyrosine phosphorylation and downstream signaling. IRS-1 deacetylation is mediated by HDAC2 and IRS-2 deacetylation is mediated by SirT1 [9395]. However, neither of these IRS posttranslational modifications have been investigated in the context of cancer and it is not known if they contribute to the regulation of IRS-dependent signaling in tumor cells.

\section{Involvement of the IRS proteins in transformation}

The transforming potential of the IRS proteins has been demonstrated in several different model systems, with most of the evidence coming from studies on IRS-1. The earliest indication that IRS- 1 had oncogenic potential came from studies on IGF-1R null 3T3 fibroblasts (Rcells), which are resistant to transformation by a number of oncogenes, including SV40 T-antigen [156,157]. Overexpression of IRS-1 in these R- cells cooperates with both SV40 T-antigen and Src to promote transformation, whereas in wildtype 3T3 cells, suppression of IRS-1 expression inhibits SV40 T-antigen-mediated transformation $[158,159]$. Subsequent studies have demonstrated that overexpression of IRS-1 in 3T3 fibroblasts, independent of SV40 T-antigen, promotes growth in soft agar and tumorigenicity in nude mice [160]. IRS-1 also cooperates with V-HA-Ras to transform 32D murine hematopoietic cells [161]. IRS-1 tyrosine phosphorylation and activation of MAPK, SHP-2 and PI3K signaling pathways have been implicated in the mechanism by which this adaptor protein promotes transformation [161-163]. Overexpression of both IRS-1 and IRS-2 in immortalized mammary epithelial cells disrupts normal luminal differentiation and polarization and promotes dysregulated growth [76]. Moreover, as mentioned previously, transgenic overexpression of IRS-1 or IRS- 2 in the mammary gland results in hyperplasia, tumor development and metastasis. Tumors that arise in response to overexpression of IRS-1 
and IRS- 2 have increased $\beta$-catenin signaling as evidenced by the upregulation of downstream target genes cyclin D1 and c-Myc [76]. These in vivo studies confirm the oncogenic potential of both of these adaptor proteins.

IRS-1 has been implicated in the development of medulloblastomas through an interaction with the T-antigen of human polyomavirus JC (JCV T-antigen). Medulloblastoma cell lines and biopsies express high levels of the IGF$1 \mathrm{R}$ and IRS-1, the latter of which co-localizes with the JCV T-antigen in the nucleus [164]. Disruption of the interaction between IRS-1 and the JCV T-antigen using a dominant negative mutant of IRS-1 inhibits the anchorageindependent growth and survival of JCV T-antigen transformed medulloblastoma cells [164]. More recently IRS-1 and IRS-4 have been shown to play a role in transformation by adenovirus 5 early region 1A (Ad5E1A) by binding to the Ad5E1A protein [165]. Ad5E1A association with the IRS proteins results in increased IRS tyrosine phosphorylation and subsequent constitutive activation of the PI3K/Akt signaling pathway.

\section{Nuclear functions for the IRS proteins}

The majority of studies that have investigated IRS function in cancer have focused on their role as cytoplasmic adaptor proteins. However, there is accumulating evidence that the IRS proteins may also have important functions in the nucleus. As mentioned above when discussing the transforming potential of the IRS proteins, IRS- 1 co-localizes with the SV40 and JCV T-antigens in the nuclei of transformed cells $[166,167]$. Independently of any oncogenic stimulus, IGF-1 stimulation can also promote the nuclear localization of IRS-1 [168]. Recently, a positive correlation between IRS-1 nuclear expression and a more welldifferentiated, non-metastatic phenotype for ductal breast cancer was reported [46]. These findings provide additional evidence that the IRS proteins may have distinct functions that are dependent upon their localization within the cell and that the activity of these adaptor proteins can be regulated by recruitment to or exclusion from a specific intracellular compartment.

With regard to function in the nucleus, IRS-1 can be detected on promoter sequences of several genes, including c-myc, Cyclin D1 and ER target genes [169,170]. Studies in breast carcinoma cells reveal interactions between IRS- 1 and the transcription factors $\beta$-catenin, ER- $\alpha$ and the androgen receptor (AR) $[76,169,171,172]$. Interactions of IRS- 1 with $\beta$-catenin and AR positively regulate transcription, whereas IRS-1 antagonizes ER-dependent expression of genes that contain estrogen response elements (EREs) [169]. Although IRS-1 is capable of directing nuclear localization of $\beta$-catenin, ER- $\alpha$ is responsible for the nuclear translocation of IRS-1 in response to estrogen treatment [169]. IRS-1 also interacts with upstream bind- ing factor-1 (UBF1) and regulates RNA polymerase activity to increase ribosomal RNA synthesis [173].

A role for IRS-1 in DNA repair has also been reported. In normal cells, IRS-1 binds to Rad51, a key enzyme in homologous recombination-directed DNA repair (HRR), and regulates its recruitment into the nucleus in response to agents that cause double strand breaks [174]. Phosphorylation of IRS-1 on tyrosine residues disrupts its interaction with Rad-51 and allows Rad51 to translocate into the nucleus to initiate DNA repair. In the absence of IGF-1 signaling, the IRS-1/Rad51 interaction is maintained and repair is impeded [174]. In medulloblastomas, IRS-1 translocates to the nucleus with ER $\beta$ or the JCV T-antigen, where it interacts with Rad51 and prevents HRR, rendering these tumors more sensitive to genotoxic agents such as cisplatin $[175,176]$.

\section{Conclusion}

The IRS proteins have been implicated in contributing to all stages of cancer, from initiating events to metastatic progression. However, there is still much to be learned about the mechanisms by which each of the IRS proteins differentially contribute to tumor cell function and the manner in which their expression and function are regulated. Understanding how the tumor microenvironment and other oncogenic signaling pathways impinge upon the IRS proteins to influence their signaling functions is essential for the future development of these adaptor proteins as either predictive markers for drug responsiveness or as therapeutic targets themselves. Given that IRS- 1 and IRS-2 mediate distinct cellular responses to IGF1stimulation, their relative expression levels and functional status are likely to impact the response of tumors to therapies that target the IGF-1 signaling axis. Assays that can determine not only the expression of the IRS family members but also their functional status will need to be developed to identify patients that are likely to be responsive to this targeted therapy and what outcomes should be anticipated.

The contribution of the IRS proteins to drug resistance is another important area for future investigation. The expression and function of the IRS proteins are tightly regulated by negative feedback loops, many of which are disrupted by drugs that target oncogenic signaling pathways. For example, prolonged inhibition of EGFR or MAPK signaling prevents the MAPK-mediated degradation of IRS-1, which increases IGF-1R signaling and resistance to EGFRinhibition therapy $[177,178]$. Likewise, resistance to rapamycin treatment can occur through the upregulation of IRS-1-mediated PI3K signaling that occurs due to the disruption of S6-kinase-mediated degradation of the IRS proteins $[138,143]$. Taken together, these studies reveal the importance of negative feedback regulation of the IRS 
proteins and underscore the importance of assessing IRS expression and function when designing new therapies that will disrupt these feedback mechanisms.

\section{Competing interests}

The authors declare that they have no competing interests.

\section{Authors' contributions}

All of the authors contributed to the writing of this manuscript. All of the authors have read and approved the final manuscript.

\section{Acknowledgements}

This work was supported by NIH grant CA090583 and Susan G. Komen for the Cure grant BCTR0706837 (LMS), American Cancer Society New England Division-Virginia Cochary Award for Excellence in Breast Cancer Research Postdoctoral Fellowship PF-07-104-0I-CSM (SLP) and Department of Defense Breast Cancer Predoctoral Fellowship BC073053 (KM).

\section{References}

I. White MF, Maron R, Kahn CR: I nsulin rapidly stimulates tyrosine phosphorylation of a Mr- 185,000 protein in intact cells. Nature 1985, 31 8(6042): |83-186.

2. Patti ME, Sun XJ, Bruening JC, Araki E, Lipes MA, White MF, Kahn CR 4PS/insulin receptor substrate (IRS)-2 is the alternative substrate of the insulin receptor in IRS-I-deficient mice. J Biol Chem 1995, 270(42):24670-24673.

3. White MF: IRS proteins and the common path to diabetes. Am J Physiol Endocrinol Metab 2002, 283(3):E4I3-422.

4. Lavan BE, Fantin VR, Chang ET, Lane WS, Keller SR, Lienhard GE: A novel $160-\mathrm{kDa}$ phosphotyrosine protein in insulin-treated embryonic kidney cells is a new member of the insulin receptor substrate family. J Biol Chem 1997, 272(34):2 I 403-2I 407.

5. Lavan BE, Lane WS, Lienhard GE: The 60-kDa phosphotyrosine protein in insulin-treated adipocytes is a new member of the insulin receptor substrate family. I Biol Chem 1997, 272( I 7): I | 439- I | 443.

6. Bjornholm M, He AR, Attersand A, Lake S, Liu SC, Lienhard GE, Taylor S, Arner $P$, Zierath JR: Absence of functional insulin receptor substrate-3 (IRS-3) gene in humans. Diabetologia 2002, 45(I2): 1697-1702.

7. Grimm J, Sachs M, Britsch S, Di Cesare S, Schwarz-Romond T, Alitalo K, Birchmeier W: Novel p62dok family members, dok-4 and dok-5, are substrates of the c-Ret receptor tyrosine kinase and mediate neuronal differentiation. I Cell Biol 200I, 154(2):345-354.

8. Favre C, Gerard A, Clauzier E, Pontarotti P, Olive D, Nunes JA DOK4 and DOK5: new Dok-related genes expressed in human T cells. Genes Immun 2003, 4(I):40-45.

9. Cai D, Dhe-Paganon S, Melendez PA, Lee J, Shoelson SE: Two new substrates in insulin signaling, IRS5/DOK4 and IRS6/DOK5. J Biol Chem 2003, 278(28):25323-25330.

10. Araki E, Lipes MA, Patti ME, Bruning JC, Haag B 3rd, Johnson RS, Kahn CR: Alternative pathway of insulin signalling in mice with targeted disruption of the IRS-I gene. Nature 1994, 372(6502): $186-190$.

II. Tamemoto H, Kadowaki T, Tobe K, Yagi T, Sakura H, Hayakawa T, Terauchi Y, Ueki K, Kaburagi Y, Satoh S, et al:: Insulin resistance and growth retardation in mice lacking insulin receptor substrate-I. Nature 1994, 372(6502): I82-186.

12. Bohni R, Riesgo-Escovar J, Oldham S, Brogiolo W, Stocker H, Andruss $B F$, Beckingham $\mathrm{K}$, Hafen $\mathrm{E}$ : Autonomous control of cell and organ size by $\mathrm{CHICO}$, a Drosophila homolog of vertebrate IRS I-4. Cell 1999, 97(7):865-875.

13. Withers DJ, Gutierrez JS, Towery H, Burks DJ, Ren JM, Previs S, Zhang Y, Bernal D, Pons S, Shulman GI, Bonner-Weir S, White MF Disruption of IRS-2 causes type 2 diabetes in mice. Nature 1998, 391 (6670):900-904.

14. Schubert M, Brazil DP, Burks DJ, Kushner JA, Ye J, Flint CL, FarhangFallah J, Dikkes P, Warot XM, Rio C, Corfas G, White MF: Insulin receptor substrate-2 deficiency impairs brain growth and promotes tau phosphorylation. J Neurosci 2003, 23(18):7084-7092.

15. Withers DJ, Burks DJ, Towery HH, Altamuro SL, Flint CL, White MF: Irs-2 coordinates Igf-I receptor-mediated beta-cell development and peripheral insulin signalling. Nat Genet 1999, 23(I):32-40

16. Burks DJ, de Mora JF, Schubert M, Withers DJ, Myers MG, Towery $\mathrm{HH}$, Altamuro SL, Flint CL, White MF: IRS-2 pathways integrate female reproduction and energy homeostasis. Nature 2000, 407(6802):377-382.

17. Fantin VR, Wang $Q$, Lienhard GE, Keller SR: Mice lacking insulin receptor substrate 4 exhibit mild defects in growth, reproduction, and glucose homeostasis. Am J Physiol Endocrinol Metab 2000, 278(I):EI27-I33.

18. Sun XJ, Rothenberg P, Kahn CR, Backer JM, Araki E, Wilden PA, Cahill DA, Goldstein BJ, White MF: Structure of the insulin receptor substrate IRS-I defines a unique signal transduction protein. Nature 1991, 352(6330):73-77.

19. Voliovitch H, Schindler DG, Hadari YR, Taylor SI, Accili D, Zick Y: Tyrosine phosphorylation of insulin receptor substrate- $I$ in vivo depends upon the presence of its pleckstrin homology region. I Biol Chem I995, 270(30): | 8083- |8087.

20. Yenush L, Makati KJ, Smith-Hall J, Ishibashi O, Myers MG Jr, White MF: The pleckstrin homology domain is the principal link between the insulin receptor and IRS-I. J Biol Chem 1996 , 27 I (39):24300-24306

21. Burks DJ, Pons S, Towery H, Smith-Hall J, Myers MG Jr, Yenush L, White MF: Heterologous pleckstrin homology domains do not couple IRS-I to the insulin receptor. IJ Biol Chem 1997, 272(44):277|6-2772।.

22. Sawka-Verhelle D, Tartare-Deckert S, White MF, Van Obberghen E: Insulin receptor substrate-2 binds to the insulin receptor through its phosphotyrosine-binding domain and through a newly identified domain comprising amino acids 59I-786. J Biol Chem 1996, 27 I (I I):5980-5983.

23. Backer JM, Wjasow C, Zhang Y: In vitro binding and phosphorylation of insulin receptor substrate $I$ by the insulin receptor. Role of interactions mediated by the phosphotyrosinebinding domain and the pleckstrin-homology domain. Eur J Biochem 1997, 245(I):91-96.

24. Sawka-Verhelle D, Baron V, Mothe I, Filloux C, White MF, Van Obberghen E: Tyr624 and Tyr628 in insulin receptor substrate-2 mediate its association with the insulin receptor. J Biol Chem 1997, 272(26): 164|4-16420.

25. Sun XJ, Crimmins DL, Myers MG Jr, Miralpeix M, White MF: Pleiotropic insulin signals are engaged by multisite phosphorylation of IRS-I. Mol Cell Biol I993, I3(I 2):74|8-7428.

26. Sun XJ, Wang LM, Zhang Y, Yenush L, Myers MG Jr, Glasheen E, Lane WS, Pierce JH, White MF: Role of IRS-2 in insulin and cytokine signalling. Nature 1995, 377(6545): 173-177.

27. Lee CH, Li W, Nishimura R, Zhou M, Batzer AG, Myers MG Jr, White MF, Schlessinger J, Skolnik EY: Nck associates with the SH2 domain-docking protein IRS-I in insulin-stimulated cells. Proc Natl Acad Sci USA 1993, 90(24): I I7| 3-1 | 7717.

28. Myers MG Jr, Grammer TC, Wang LM, Sun XJ, Pierce JH, Blenis J White MF: Insulin receptor substrate-I mediates phosphatidylinositol 3'-kinase and p7056k signaling during insulin, insulin-like growth factor-I, and interleukin-4 stimulation. J Biol Chem 1994, 269(46):28783-28789

29. Myers MG Jr, Wang LM, Sun XJ, Zhang Y, Yenush L, Schlessinger J, Pierce JH, White MF: Role of IRS- I-GRB-2 complexes in insulin signaling. Mol Cell Biol 1994, 14(6):3577-3587.

30. Beitner-Johnson D, Blakesley VA, Shen-Orr Z, Jimenez M, Stannard B, Wang LM, Pierce J, LeRoith D: The proto-oncogene product cCrk associates with insulin receptor substrate-I and 4PS. Modulation by insulin growth factor-I (IGF) and enhanced IGF-I signaling. J Biol Chem 1996, 27 I (16):9287-9290.

31. Myers MG Jr, Mendez R, Shi P, Pierce JH, Rhoads R, White MF: The COOH-terminal tyrosine phosphorylation sites on IRS-I bind SHP-2 and negatively regulate insulin signaling. J Biol Chem 1998, 273(4I):26908-26914.

32. Karas M, Koval AP, Zick $Y$, LeRoith $D$ : The insulin-like growth factor I receptor-induced interaction of insulin receptor substrate-4 and Crk-II. Endocrinology 200I, I42(5):1835-1840. 
33. Hanke S, Mann M: The phosphotyrosine interactome of the insulin receptor family and its substrates IRS-I and IRS-2. Mol Cell Proteomics 2009, 8(3):519-534.

34. Bergmann U, Funatomi H, Kornmann M, Beger HG, Korc $M$ Increased expression of insulin receptor substrate-I in human pancreatic cancer. Biochem Biophys Res Commun 1996, 220(3):886-890.

35. Kornmann M, Maruyama H, Bergmann U, Tangvoranuntakul P, Beger HG, White MF, Korc M: Enhanced expression of the insulin receptor substrate- 2 docking protein in human pancreatic cancer. Cancer Res 1998, 58(19):4250-4254.

36. Hellawell GO, Turner GD, Davies DR, Poulsom R, Brewster SF, Macaulay VM: Expression of the type I insulin-like growth factor receptor is up-regulated in primary prostate cancer and commonly persists in metastatic disease. Cancer Res 2002 62(1 0):2942-2950.

37. Hoang CD, Zhang X, Scott PD, Guillaume TJ, Maddaus MA, Yee D, Kratzke RA: Selective activation of insulin receptor substrate$I$ and -2 in pleural mesothelioma cells: association with distinct malignant phenotypes. Cancer Res 2004 64(20):7479-7485.

38. Boissan M, Beurel E, Wendum D, Rey C, Lecluse Y, Housset C, Lacombe ML, Desbois-Mouthon C: Overexpression of insulin receptor substrate-2 in human and murine hepatocellular carcinoma. Am J Pathol 2005, I67(3):869-877.

39. Cantarini MC, de la Monte SM, Pang M, Tong M, D'Errico A, Trevisan F, Wands JR: Aspartyl-asparagyl beta hydroxylase overexpression in human hepatoma is linked to activation of insulin-like growth factor and notch signaling mechanisms. Hepatology 2006, 44(2):446-457.

40. Szabolcs M, Keniry M, Simpson L, Reid LJ, Koujak S, Schiff SC, Davidian G, Licata S, Gruvberger-Saal S, Murty VV, Nandula S, Efstratiadis A, Kushner JA, White MF, Parsons R: Irs2 inactivation suppresses tumor progression in Pten +/- mice. Am I Pathol 2009 I 74(I):276-286

4I. Rocha RL, Hilsenbeck SG, Jackson JG, VanDenBerg CL, Weng C, Lee $A V$, Yee D: Insulin-like growth factor binding protein-3 and insulin receptor substrate-I in breast cancer: correlation with clinical parameters and disease-free survival. Clin Cancer Res 1997, 3(1): 103-109.

42. Del Valle L, Enam S, Lassak A, Wang JY, Croul S, Khalili K, Reiss K: Insulin-like growth factor I receptor activity in human medulloblastomas. Clin Cancer Res 2002, 8(6): | 822- | 830.

43. Koda M, Sulkowska M, Kanczuga-Koda L, Sulkowski S: Expression of insulin receptor substrate $I$ in primary breast cancer and lymph node metastases. J Clin Pathol 2005, 58(6):645-649.

44. Ravikumar S, Perez-Liz G, Del Vale L, Soprano DR, Soprano KJ: Insulin receptor substrate-I is an important mediator of ovarian cancer cell growth suppression by all-trans retinoic acid. Cancer Res 2007, 67( I 9):9266-9275.

45. Schnarr B, Strunz K, Ohsam J, Benner A, Wacker J, Mayer D: Downregulation of insulin-like growth factor-I receptor and insulin receptor substrate-I expression in advanced human breast cancer. Int J Cancer 2000, 89(6):506-5I3.

46. Sisci D, Morelli C, Garofalo C, Romeo F, Morabito L, Casaburi F, Middea E, Cascio S, Brunelli E, Ando S, Surmacz E: Expression of nuclear insulin receptor substrate I (IRS-I) in breast cancer. J Clin Pathol 2006, 60:633-641.

47. Han CH, Cho JY, Moon JT, Kim HJ, Kim SK, Shin DH, Chang J, Ahn CM, Kim SK, Chang YS: Clinical significance of insulin receptor substrate-I down-regulation in non-small cell lung cancer. Oncol Rep 2006, I6(6): I205-1210.

48. Al-Sarraf N, Reiff JN, Hinrichsen J, Mahmood S, Teh BT, McGovern E, De Meyts P, O'Byrne KJ, Gray SG: DOK4/IRS-5 expression is altered in clear cell renal cell carcinoma. Int J Cancer 2007 , | 2 | (5):992-998.

49. Gual $P$, Le Marchand-Brustel $Y$, Tanti JF: Positive and negative regulation of insulin signaling through IRS-I phosphorylation. Biochimie 2005, 87(I):99-109.

50. Sachdev D, Yee D: The IGF system and breast cancer. Endocr Relat Cancer 200I, 8(3): 197-209.

5I. LeRoith D, Roberts CT Jr: The insulin-like growth factor system and cancer. Cancer Lett 2003, I 95(2): I27-137.

52. Resnik JL, Reichart DB, Huey K, Webster NJ, Seely BL: Elevated insulin-like growth factor I receptor autophosphorylation and kinase activity in human breast cancer. Cancer Res 1998 , 58(6): I I59- I | 64

53. Renehan AG, Zwahlen M, Minder C, O'Dwyer ST, Shalet SM, Egger M: Insulin-like growth factor (IGF)-I, IGF binding protein-3, and cancer risk: systematic review and meta-regression analysis. Lancet 2004, 363(94 | 8): I 346- I 353.

54. Yamauchi T, Kaburagi Y, Ueki K, Tsuji Y, Stark GR, Kerr IM, Tsushima T, Akanuma Y, Komuro I, Tobe K, Yazaki Y, Kadowaki T: Growth hormone and prolactin stimulate tyrosine phosphorylation of insulin receptor substrate- I, -2 , and -3 , their association with p85 phosphatidylinositol 3-kinase (PI3-kinase), and concomitantly PI3-kinase activation via JAK2 kinase. J Biol Chem 1998, 273(25): I57|9-|5726.

55. Liang L, Zhou T, Jiang J, Pierce JH, Gustafson TA, Frank SJ: Insulin receptor substrate-I enhances growth hormone-induced proliferation. Endocrinology 1999, I40(5): 1972-1983.

56. Senthil D, Ghosh Choudhury G, Bhandari BK, Kasinath BS: The type $\mathbf{2}$ vascular endothelial growth factor receptor recruits insulin receptor substrate-I in its signalling pathway. Biochem J 2002 , 368(Pt I):49-56.

57. Morgillo F, Woo JK, Kim ES, Hong WK, Lee HY: Heterodimerization of insulin-like growth factor receptor/epidermal growth factor receptor and induction of survivin expression counteract the antitumor action of erlotinib. Cancer Res 2006, 66(20): $10100-10111$.

58. Knowlden JM, Jones HE, Barrow D, Gee JM, Nicholson RI, Hutcheson IR: Insulin receptor substrate-I involvement in epidermal growth factor receptor and insulin-like growth factor receptor signalling: implication for Gefitinib ('Iressa') response and resistance. Breast Cancer Res Treat 2008, I I I (I):79-9 I.

59. Vuori K, Ruoslahti E: Association of insulin receptor substrateI with integrins. Science 1994, 266(5 I 90): I576-I578.

60. Shaw LM: Identification of insulin receptor substrate I (IRS-I) and IRS-2 as signaling intermediates in the alpha6beta4 integrin-dependent activation of phosphoinositide 3-OH kinase and promotion of invasion. Mol Cell Biol 200I, 2 I ( I 5):5082-5093.

6I. Goel HL, Fornaro M, Moro L, Teider N, Rhim JS, King M, Languino LR: Selective modulation of type I insulin-like growth factor receptor signaling and functions by betal integrins. J Cell Biol 2004, I 66(3):407-4I8.

62. Fujimoto J, Shiota M, Iwahara T, Seki N, Satoh H, Mori S, Yamamoto $\mathrm{T}$ : Characterization of the transforming activity of p80, a hyperphosphorylated protein in a Ki-I lymphoma cell line with chromosomal translocation t(2;5). Proc Natl Acad Sci USA 1996, 93(9):4|8|-4|86.

63. Miyagi E, Braga-Basaria M, Hardy E, Vasko V, Burman KD, Jhiang S, Saji M, Ringel MD: Chronic expression of RET/PTC 3 enhances basal and insulin-stimulated PI3 kinase/AKT signaling and increases IRS-2 expression in FRTL-5 thyroid cells. Mol Carcinog 2004, 4 I (2):98-107.

64. Lannon CL, Sorensen PH: ETV6-NTRK3: a chimeric protein tyrosine kinase with transformation activity in multiple cell lineages. Semin Cancer Biol 2005, I 5(3):215-223.

65. Stoica GE, Kuo A, Aigner A, Sunitha I, Souttou B, Malerczyk C, Caughey DJ, Wen D, Karavanov A, Riegel AT, Wellstein A: Identification of anaplastic lymphoma kinase as a receptor for the growth factor pleiotrophin. I Biol Chem 2001, 276(20): 16772-16779.

66. Nolan MK, Jankowska L, Prisco M, Xu S, Guvakova MA, Surmacz E: Differential roles of IRS-I and SHC signaling pathways in breast cancer cells. Int J Cancer 1997, 72(5):828-834.

67. Jackson JG, White MF, Yee D: Insulin receptor substrate-I is the predominant signaling molecule activated by insulin-like growth factor-I, insulin, and interleukin-4 in estrogen receptor-positive human breast cancer cells. J Biol Chem 1998 , 273( I 6):9994-10003.

68. Taouis M, Dupont J, Gillet A, Derouet $M$, Simon J: Insulin receptor substrate I antisense expression in an hepatoma cell line reduces cell proliferation and induces overexpression of the Src homology 2 domain and collagen protein (SHC). Mol Cell Endocrinol 1998, 137(2): 177-186.

69. Wang JY, Del Valle L, Gordon J, Rubini M, Romano G, Croul S, Peruzzi F, Khalili K, Reiss K: Activation of the IGF-IR system contributes to malignant growth of human and mouse medulloblastomas. Oncogene 200I, 20(29):3857-3868. 
70. Byron SA, Horwitz KB, Richer JK, Lange CA, Zhang X, Yee D: Insulin receptor substrates mediate distinct biological responses to insulin-like growth factor receptor activation in breast cancer cells. $\mathrm{Br} J$ Cancer 2006, 95(9): | 220-| 228.

7I. Tanaka S, Wands JR: A carboxy-terminal truncated insulin receptor substrate-I dominant negative protein reverses the human hepatocellular carcinoma malignant phenotype. J Clin Invest 1996, 98(9):2100-2108.

72. Weng LP, Smith WM, Brown JL, Eng C: PTEN inhibits insulinstimulated MEK/MAPK activation and cell growth by blocking IRS-I phosphorylation and IRS-I/Grb-2/Sos complex formation in a breast cancer model. Hum Mol Genet 200I, I0(6):605-6I6.

73. Tanaka S, Wands JR: Insulin receptor substrate I overexpression in human hepatocellular carcinoma cells prevents transforming growth factor betal-induced apoptosis. Cancer Res 1996, 56(I5):3391-3394.

74. Cesarone G, Garofalo C, Abrams MT, Igoucheva O, Alexeev V, Yoon $\mathrm{K}$, Surmacz E, Wickstrom E: RNAi-mediated silencing of insulin receptor substrate I (IRS-I) enhances tamoxifen-induced cell death in MCF-7 breast cancer cells. J Cell Biochem 2006, 98(2):440-450.

75. Nagle JA, Ma Z, Byrne MA, White MF, Shaw LM: Involvement of insulin receptor substrate 2 in mammary tumor metastasis. Mol Cell Biol 2004, 24(22):9726-9735.

76. Dearth RK, Cui X, Kim HJ, Kuiatse I, Lawrence NA, Zhang X, Divisova J, Britton OL, Mohsin S, Allred DC, Hadsell DL, Lee AV: Mammary tumorigenesis and metastasis caused by overexpression of insulin receptor substrate I (IRS-I) or IRS-2. Mol Cell Biol 2006, 26(24):9302-93I4.

77. Tanaka S, Mohr L, Schmidt EV, Sugimachi K, Wands JR: Biological effects of human insulin receptor substrate- I overexpression in hepatocytes. Hepatology 1997, 26(3):598-604.

78. Wiedmann M, Tamaki S, Silberman R, de la Monte SM, Cousens L Wands JR: Constitutive over-expression of the insulin receptor substrate-I causes functional up-regulation of Fas receptor. I Hepatol 2003, 38(6):803-8I0.

79. Ma Z, Gibson SL, Byrne MA, Zhang J, White MF, Shaw LM: Suppression of insulin receptor substrate I (IRS-I) promotes mammary tumor metastasis. Mol Cell Biol 2006, 26(24):9338-935I.

80. Gibson SL, Ma Z, Shaw LM: Divergent roles for IRS-I and IRS-2 in breast cancer metastasis. Cell Cycle 2007, 6(6):63 I-637.

81. Ramocki NM, Wilkins HR, Magness ST, Simmons JG, Scull BP, Lee $\mathrm{GH}$, McNaughton KK, Lund PK: Insulin receptor substrate-I deficiency promotes apoptosis in the putative intestinal crypt stem cell region, limits Apcmin/+ tumors, and regulates Sox9. Endocrinology 2008, I 49(I):26I-267.

82. Dunn SE, Ehrlich M, Sharp NJ, Reiss K, Solomon G, Hawkins R, Baserga R, Barrett JC: A dominant negative mutant of the insulin-like growth factor-I receptor inhibits the adhesion, invasion, and metastasis of breast cancer. Cancer Res 1998 58(15):3353-336I.

83. Sachdev D, Hartell JS, Lee AV, Zhang X, Yee D: A dominant negative type I insulin-like growth factor receptor inhibits metastasis of human cancer cells. J Biol Chem 2004, 279(6):5017-5024.

84. Jackson JG, Zhang X, Yoneda T, Yee D: Regulation of breast cancer cell motility by insulin receptor substrate-2 (IRS-2) in metastatic variants of human breast cancer cell lines. Oncogene 200I, 20(50):73I8-7325.

85. Zhang X, Kamaraju S, Hakuno F, Kabuta T, Takahashi S, Sachdev D, Yee D: Motility response to insulin-like growth factor-I (IGFI) in MCF-7 cells is associated with IRS-2 activation and integrin expression. Breast Cancer Res Treat 2004, 83(2): I6I-I70.

86. Cui X, Kim HJ, Kuiatse I, Kim H, Brown PH, Lee AV: Epiderma Growth Factor Induces Insulin Receptor Substrate-2 in Breast Cancer Cells via c-Jun NH2-Terminal Kinase/Activator Protein-I Signaling to Regulate Cell Migration. Cancer Res 2006, 66(I 0):5304-53I3.

87. Kim B, Leventhal PS, White MF, Feldman EL: Differential regulation of insulin receptor substrate- 2 and mitogen-activated protein kinase tyrosine phosphorylation by phosphatidylinositol 3-kinase inhibitors in SH-SY5Y human neuroblastoma cells. Endocrinology I998, I39( I 2):488I-4889.

88. Pankratz SL, Tan EY, Fine Y, Mercurio AM, Shaw LM: Insulin receptor substrate-2 regulates aerobic glycolysis in mouse mam- mary tumor cells via glucose transporter I. J Biol Chem 2009. 284(4):203।-2037

89. Kwon J, Stephan S, Mukhopadhyay A, Muders MH, Dutta SK, Lau JS, Mukhopadhyay D: Insulin receptor substrate-2 mediated insulin-like growth factor-I receptor overexpression in pancreatic adenocarcinoma through protein kinase Cdelta. Cancer Res 2009, 69(4): |350-1357.

90. Myers MG Jr, Backer JM, Sun XJ, Shoelson S, Hu P, Schlessinger J, Yoakim M, Schaffhausen B, White MF: IRS-I activates phosphatidylinositol 3'-kinase by associating with src homology 2 domains of p85. Proc Natl Acad Sci USA 1 992, 89(2 I): I0350-I 0354.

91. Zhang X, Lin M, van Golen KL, Yoshioka K, Itoh K, Yee D: Multiple signaling pathways are activated during insulin-like growth factor-I (IGF-I) stimulated breast cancer cell migration. Breast Cancer Res Treat 2005, 93(2): I59-I68.

92. Fasshauer M, Klein J, Ueki K, Kriauciunas KM, Benito M, White MF, Kahn CR: Essential role of insulin receptor substrate-2 in insulin stimulation of Glut4 translocation and glucose uptake in brown adipocytes. J Biol Chem 2000, 275(33):25494-2550I.

93. Kaiser C, James SR: Acetylation of insulin receptor substrate-I is permissive for tyrosine phosphorylation. BMC Biol 2004, 2:23.

94. Zhang J: The direct involvement of SirTI in insulin-induced insulin receptor substrate- 2 tyrosine phosphorylation. J Biol Chem 2007, 282(47):34356-34364.

95. Li Y, Xu W, McBurney MW, Longo VD: SirT I inhibition reduces IGF-I/IRS-2/Ras/ERKI/2 signaling and protects neurons. Cell Metab 2008, 8(I):38-48.

96. Guo S, Dunn SL, White MF: The reciprocal stability of FOXOI and IRS2 creates a regulatory circuit that controls insulin signaling. Mol Endocrinol 2006, 20( I 2):3389-3399.

97. Escribano O, Fernandez-Moreno MD, Zueco JA, Menor C, Fueyo J, Ropero RM, Diaz-Laviada I, Roman ID, Guijarro LG: Insulin receptor substrate-4 signaling in quiescent rat hepatocytes and in regenerating rat liver. Hepatology 2003, 37(6): | 46 |- | 469.

98. Cuevas EP, Escribano O, Chiloeches A, Ramirez Rubio S, Roman ID, Fernandez-Moreno MD, Guijarro LG: Role of insulin receptor substrate-4 in IGF-I-stimulated HEPG2 proliferation. J Hepatol 2007, 46(6): 1089-1098.

99. Urso B, llondo MM, Holst PA, Christoffersen CT, Ouwens M, Giorgetti S, Van Obberghen E, Naor D, Tornqvist H, De Meyts P: IRS-4 mediated mitogenic signalling by insulin and growth hormone in LB cells, a murine T-cell lymphoma devoid of IGF-I receptors. Cell Signal 2003, I 5(4):385-394.

100. Karrman K, Kjeldsen E, Lassen C, Isaksson M, Davidsson J, Andersson $A$, Hasle H, Fioretos T, Johansson B: The $t(X ; 7)(q 22 ; q 34)$ in paediatric $T$-cell acute lymphoblastic leukaemia results in overexpression of the insulin receptor substrate 4 gene through illegitimate recombination with the $\mathrm{T}$-cell receptor beta locus. Br J Haematol 2009, I 44(4):546-55I.

10I. Guvakova MA, Surmacz E: Tamoxifen interferes with the insulin-like growth factor I receptor (IGF-IR) signaling pathway in breast cancer cells. Cancer Res 1997, 57(13):2606-26I0.

102. Salerno M, Sisci D, Mauro L, Guvakova MA, Ando S, Surmacz E: Insulin receptor substrate $I$ is a target for the pure antiestrogen ICI I82,780 in breast cancer cells. Int J Cancer I999, 8 I (2):299-304.

103. Lee AV, Jackson JG, Gooch JL, Hilsenbeck SG, Coronado-Heinsohn E, Osborne CK, Yee D: Enhancement of insulin-like growth factor signaling in human breast cancer: estrogen regulation of insulin receptor substrate-I expression in vitro and in vivo. Mol Endocrinol 1999, I3(5):787-796.

104. Molloy CA, May FE, Westley BR: Insulin receptor substrate-I expression is regulated by estrogen in the MCF-7 human breast cancer cell line [In Process Citation]. J Biol Chem 2000 , 275(I7): | 2565-|257|

105. Vassen L, Wegrzyn W, Klein-Hitpass L: Human insulin receptor substrate-2 (IRS-2) is a primary progesterone response gene. Mol Endocrinol 1999, I 3(3):485-494.

106. Cui X, Lazard Z, Zhang P, Hopp TA, Lee AV: Progesterone crosstalks with insulin-like growth factor signaling in breast cancer cells via induction of insulin receptor substrate-2. Oncogene 2003, 22(44):6937-694I.

107. Ibrahim YH, Byron SA, Cui X, Lee AV, Yee D: Progesterone receptor-B regulation of insulin-like growth factor-stimulated cell 
migration in breast cancer cells via insulin receptor substrate-2. Mol Cancer Res 2008, 6(9): 149I-I 498.

108. Matsuda K, Araki E, Yoshimura R, Tsuruzoe K, Furukawa N, Kaneko $\mathrm{K}$, Motoshima H, Yoshizato K, Kishikawa H, Shichiri M: Cell-specific regulation of IRS-I gene expression: role of $E$ box and C/EBP binding site in HepG2 cells and CHO cells. Diabetes 1997, 46(3):354-362.

109. Jhala US, Canettieri G, Screaton RA, Kulkarni RN, Krajewski S, Reed J, Walker J, Lin X, White M, Montminy M: cAMP promotes pancreatic beta-cell survival via CREB-mediated induction of IRS2. Genes Dev 2003, I7(13): 1575-1580.

I 10. Ide T, Shimano H, Yahagi N, Matsuzaka T, Nakakuki M, Yamamoto T, Nakagawa Y, Takahashi A, Suzuki H, Sone H, Toyoshima H, Fukamizu A, Yamada N: SREBPs suppress IRS-2-mediated insulin signalling in the liver. Nat Cell Biol 2004, 6(4):35 I-357.

III. Zhang J, Ou J, Bashmakov Y, Horton JD, Brown MS, Goldstein JL: Insulin inhibits transcription of IRS-2 gene in rat liver through an insulin response element (IRE) that resembles IREs of other insulin-repressed genes. Proc Natl Acad Sci USA 200I, 98(7):3756-376I.

I 12. Hirashima Y, Tsuruzoe K, Kodama S, Igata M, Toyonaga T, Ueki K, Kahn CR, Araki E: Insulin down-regulates insulin receptor substrate-2 expression through the phosphatidylinositol 3kinase/Akt pathway. J Endocrinol 2003, I 79(2):253-266.

1 13. Lassarre C, Ricort JM: Growth factor-specific regulation of insulin receptor substrate-I expression in MCF-7 breast carcinoma cells: effects on the insulin-like growth factor signaling pathway. Endocrinology 2003, I 44(I I):48II-48I9.

I 14. Kuang SQ, Liao L, Zhang H, Lee AV, O'Malley BW, Xu J: AIB I/SRC3 deficiency affects insulin-like growth factor I signaling pathway and suppresses v-Ha-ras-induced breast cancer initiation and progression in mice. Cancer Res 2004, 64(5): | 875- 1885.

115. Yan J, Yu CT, Ozen M, Ittmann M, Tsai SY, Tsai MJ: Steroid receptor coactivator-3 and activator protein-I coordinately regulate the transcription of components of the insulin-like growth factor/AKT signaling pathway. Cancer Res 2006, 66(22): II039-II 046.

116. Yan J, Tsai SY, Tsai MJ: SRC-3/AIB I: transcriptional coactivator in oncogenesis. Acta Pharmacol Sin 2006, 27(4):387-394.

I 17. Kuang SQ, Liao L, Wang S, Medina D, O'Malley BW, Xu J: Mice lacking the amplified in breast cancer I/steroid receptor coactivator-3 are resistant to chemical carcinogen-induced mammary tumorigenesis. Cancer Res 2005, 65(I7):7993-8002.

118. Welcsh PL, King MC: BRCAI and BRCA2 and the genetics of breast and ovarian cancer. Hum Mol Genet 200I, I 0(7):705-7I3.

1 19. Shukla V, Coumoul X, Cao L, Wang RH, Xiao C, Xu X, Ando S, Yakar $S$, Leroith $D$, Deng $C$ : Absence of the full-length breast cancerassociated gene-I leads to increased expression of insulinlike growth factor signaling axis members. Cancer Res 2006, 66(14):715I-7|57.

120. Shi B, Sepp-Lorenzino L, Prisco M, Linsley P, deAngelis T, Baserga R: Micro RNA I 45 targets the insulin receptor substrate- $I$ and inhibits the growth of colon cancer cells. J Biol Chem 2007, 282(45):32582-32590.

121. Zhang J, Du YY, Lin YF, Chen YT, Yang L, Wang HJ, Ma D: The cell growth suppressor, mir-I 26, targets IRS-I. Biochem Biophys Res Commun 2008, 377(I): $136-140$

122. La Rocca G, Badin M, Shi B, Xu SQ, Deangelis T, Sepp-Lorenzinoi L, Baserga R: Mechanism of growth inhibition by MicroRNA I45: The role of the IGF-I receptor signaling pathway. J Cell Physiol 2009, 220(2):485-49l.

123. lorio MV, Ferracin M, Liu CG, Veronese A, Spizzo R, Sabbioni S, Magri E, Pedriali M, Fabbri M, Campiglio M, Ménard S, Palazzo JP, Rosenberg A, Musiani P, Volinia S, Nenci I, Calin GA, Querzoli P, Negrini M, Croce CM: MicroRNA gene expression deregulation in human breast cancer. Cancer Res 2005, 65(16):7065-7070.

124. Schepeler T, Reinert JT, Ostenfeld MS, Christensen LL, Silahtaroglu AN, Dyrskjot L, Wiuf C, Sorensen FJ, Kruhoffer M, Laurberg S, Kauppinen S, Ørntoft TF, Andersen CL: Diagnostic and prognostic microRNAs in stage II colon cancer. Cancer Res 2008, 68(15):6416-6424.

125. Xu N, Papagiannakopoulos T, Pan G, Thomson JA, Kosik KS: MicroRNA- 145 regulates OCT4, SOX2, and KLF4 and represses pluripotency in human embryonic stem cells. Cell 2009, 137(4):647-658.
126. Rubin R, Arzumanyan A, Soliera AR, Ross B, Peruzzi F, Prisco M: Insulin receptor substrate (IRS)-I regulates murine embryonic stem (mES) cells self-renewal. J Cell Physiol 2007, 213(2):445-453.

127. Aguirre V, Uchida T, Yenush L, Davis R, White MF: The c-Jun $\mathrm{NH}(2)$-terminal kinase promotes insulin resistance during association with insulin receptor substrate-I and phosphorylation of Ser(307). J Biol Chem 2000, 275( I 2):9047-9054.

128. Um SH, Frigerio F, Watanabe M, Picard F, Joaquin M, Sticker M, Fumagalli S, Allegrini PR, Kozma SC, Auwerx J, Thomas G: Absence of S6KI protects against age- and diet-induced obesity while enhancing insulin sensitivity. Nature 2004, 43 I (7005):200-205.

129. Liberman Z, Eldar-Finkelman H: Serine 332 phosphorylation of insulin receptor substrate- $I$ by glycogen synthase kinase-3 attenuates insulin signaling. I Biol Chem 2005, 280(6):4422-4428.

130. Paz K, Hemi R, LeRoith D, Karasik A, Elhanany E, Kanety H, Zick Y: A molecular basis for insulin resistance. Elevated serinel threonine phosphorylation of IRS-I and IRS-2 inhibits their binding to the juxtamembrane region of the insulin receptor and impairs their ability to undergo insulin-induced tyrosine phosphorylation. J Biol Chem 1997, 272(47):299|I-299।8.

131. Aguirre V, Werner ED, Giraud J, Lee YH, Shoelson SE, White MF: Phosphorylation of Ser307 in insulin receptor substrate-I blocks interactions with the insulin receptor and inhibits insulin action. J Biol Chem 2002, 277(2): $1531-1537$.

132. Liu YF, Paz K, Herschkovitz A, Alt A, Tennenbaum T, Sampson SR, Ohba M, Kuroki T, LeRoith D, Zick Y: Insulin stimulates PKCzeta-mediated phosphorylation of insulin receptor substrate-I (IRS-I). A self-attenuated mechanism to negatively regulate the function of IRS proteins. J Biol Chem 200I, 276(17): | 14459-14465.

133. Ogihara T, Isobe $T$, Ichimura $T$, Taoka M, Funaki M, Sakoda $H$, Onishi Y, Inukai K, Anai M, Fukushima Y, Kikuchi M, Yazaki Y, Oka Y, Asano $T$ : I 4-3-3 protein binds to insulin receptor substrate-I, one of the binding sites of which is in the phosphotyrosine binding domain. J Biol Chem 1997, 272(40):25267-25274.

134. Tzatsos A, Kandror KV: Nutrients suppress phosphatidylinositol 3-kinase/Akt signaling via raptor-dependent mTORmediated insulin receptor substrate I phosphorylation. Mol Cell Biol 2006, 26(I):63-76.

135. Delahaye L, Mothe-Satney I, Myers MG, White MF, Van Obberghen $E$ : Interaction of insulin receptor substrate-I (IRS-I) with phosphatidylinositol 3-kinase: effect of substitution of serine for alanine in potential IRS-I serine phosphorylation sites. Endocrinology 1998, I39(I2):49||-49|9.

136. Luo M, Reyna S, Wang L, Yi Z, Carroll C, Dong LQ, Langlais P, Weintraub ST, Mandarino LJ: Identification of insulin receptor substrate I serine/threonine phosphorylation sites using mass spectrometry analysis: regulatory role of serine 1223 . Endocrinology 2005, I 46( I 0):44I 0-44I6.

137. Rui L, Fisher TL, Thomas J, White MF: Regulation of insulin/insulin-like growth factor-I signaling by proteasome-mediated degradation of insulin receptor substrate-2. J Biol Chem 200I, 276(43):40362-40367.

138. O'Reilly KE, Rojo F, She QB, Solit D, Mills GB, Smith D, Lane H, Hofmann F, Hicklin DJ, Ludwig DL, Baselga J, Rosen N: mTOR inhibition induces upstream receptor tyrosine kinase signaling and activates Akt. Cancer Res 2006, 66(3): $1500-1508$.

139. Lee AV, Gooch JL, Oesterreich S, Guler RL, Yee D: Insulin-like growth factor I-induced degradation of insulin receptor substrate $I$ is mediated by the $26 \mathrm{~S}$ proteasome and blocked by phosphatidylinositol 3'-kinase inhibition. Mol Cell Biol 2000, 20(5): $1489-1496$.

140. Greene MW, Sakaue H, Wang L, Alessi DR, Roth RA: Modulation of insulin-stimulated degradation of human insulin receptor substrate-I by Serine 312 phosphorylation. J Biol Chem 2003, 278(10):8|99-82II.

14I. Hiratani K, Haruta T, Tani A, Kawahara J, Usui I, Kobayashi M: Roles of $\mathrm{MTOR}$ and JNK in serine phosphorylation, translocation, and degradation of IRS-I. Biochem Biophys Res Commun 2005, 335(3):836-842.

142. Briaud I, Dickson LM, Lingohr MK, McCuaig JF, Lawrence JC, Rhodes $\mathrm{CJ}$ : Insulin receptor substrate-2 proteasomal degradation mediated by a mammalian target of rapamycin (mTOR)induced negative feedback down-regulates protein kinase B- 
mediated signaling pathway in beta-cells. J Biol Chem 2005, 280(3):2282-2293.

143. Shah OJ, Wang Z, Hunter T: Inappropriate activation of the TSC/Rheb/mTOR/S6K cassette induces IRSI/2 depletion, insulin resistance, and cell survival deficiencies. Curr Biol 2004, I4(18): 1650-1656.

144. Harrington LS, Findlay GM, Gray A, Tolkacheva T, Wigfield S, Rebholz H, Barnett J, Leslie NR, Cheng S, Shepherd PR, Gout I, Downes CP, Lamb RF: The TSCI-2 tumor suppressor controls insulinPI3K signaling via regulation of IRS proteins. J Cell Biol 2004, 166(2):2। $3-223$.

145. Carlson CI, White MF, Rondinone CM: Mammalian target of rapamycin regulates IRS-I serine 307 phosphorylation. Biochem Biophys Res Commun 2004, 3 I 6(2):533-539.

146. Manning BD, Logsdon MN, Lipovsky Al, Abbott D, Kwiatkowski DJ, Cantley LC: Feedback inhibition of Akt signaling limits the growth of tumors lacking Tsc2. Genes Dev 2005, 19(15): I773-1778.

147. Ozcan U, Ozcan L, Yilmaz E, Duvel K, Sahin M, Manning BD, Hotamisligil GS: Loss of the tuberous sclerosis complex tumor suppressors triggers the unfolded protein response to regulate insulin signaling and apoptosis. Mol Cell 2008, 29(5):54I-55I.

148. de Visser KE, Eichten A, Coussens LM: Paradoxical roles of the immune system during cancer development. Nat Rev Cancer 2006, 6(I):24-37.

149. Senzaki H, Iwamoto S, Ogura E, Kiyozuka Y, Arita S, Kurebayashi J, Takada H, Hioki K, Tsubura A: Dietary effects of fatty acids on growth and metastasis of KPL-I human breast cancer cells in vivo and in vitro. Anticancer Res 1998, 18(3A): |62I-1627.

150. Brown NS, Bicknell R: Hypoxia and oxidative stress in breast cancer. Oxidative stress: its effects on the growth, metastatic potential and response to therapy of breast cancer. Breast Cancer Res 200I, 3(5):323-327.

15I. Carmichael AR: Obesity and prognosis of breast cancer. Obes Rev 2006, 7(4):333-340.

152. Lorincz AM, Sukumar S: Molecular links between obesity and breast cancer. Endocr Relat Cancer 2006, I3(2):279-292.

153. White MF: Regulating insulin signaling and beta-cell function through IRS proteins. Can J Physiol Pharmacol 2006, 84(7):725-737.

154. Patti ME, Virkamaki A, Landaker EJ, Kahn CR, Yki-Jarvinen H: Activation of the hexosamine pathway by glucosamine in vivo induces insulin resistance of early postreceptor insulin signaling events in skeletal muscle. Diabetes 1999, 48(8): I562-I57|.

155. D'Alessandris C, Andreozzi F, Federici M, Cardellini M, Brunetti A, Ranalli M, Del Guerra S, Lauro D, Del Prato S, Marchetti P, Lauro R, Sesti G: Increased O-glycosylation of insulin signaling proteins results in their impaired activation and enhanced susceptibility to apoptosis in pancreatic beta-cells. Faseb J 2004, I 8(9):959-96I.

156. Sell C, Rubini M, Rubin R, Liu JP, Efstratiadis A, Baserga R: Simian virus $\mathbf{4 0}$ large tumor antigen is unable to transform mouse embryonic fibroblasts lacking type $I$ insulin-like growth factor receptor. Proc Natl Acad Sci USA 1993, 90(23): I I2 I 7-I I 22 I.

157. Sell C, Dumenil G, Deveaud C, Miura M, Coppola D, DeAngelis T, Rubin R, Efstratiadis A, Baserga R: Effect of a null mutation of the insulin-like growth factor I receptor gene on growth and transformation of mouse embryo fibroblasts. Mol Cell Biol 1994, I4(6):3604-3612

158. D'Ambrosio C, Keller SR, Morrione A, Lienhard GE, Baserga R, Surmacz $E$ : Transforming potential of the insulin receptor substrate I. Cell Growth Differ 1995, 6(5):557-562.

159. Sun $H$, Baserga $R$ : The role of insulin receptor substrate-I in transformation by v-src. / Cell Physiol 2008, 2 I 5(3):725-732.

160. Ito T, Sasaki Y, Wands JR: Overexpression of human insulin receptor substrate $I$ induces cellular transformation with activation of mitogen-activated protein kinases. Mol Cell Biol 1996, I 6(3):943-95I.

16I. Cristofanelli B, Valentinis B, Soddu S, Rizzo MG, Marchetti A, Bossi G, Morena AR, Dews M, Baserga R, Sacchi A: Cooperative transformation of 32D cells by the combined expression of IRS-I and V-Ha-Ras. Oncogene 2000, I 9(29):3245-3255.

162. Tanaka S, Ito T, Wands JR: Neoplastic transformation induced by insulin receptor substrate-I overexpression requires an interaction with both Grb2 and Syp signaling molecules. J Biol Chem 1996, 27 I(24): |46|0-|46|6.
163. DeAngelis T, Chen J, Wu A, Prisco M, Baserga R: Transformation by the simian virus $\mathbf{4 0} \mathrm{T}$ antigen is regulated by IGF-I receptor and IRS-I signaling. Oncogene 2006, 25(I):32-42.

164. Del Valle L, Wang JY, Lassak A, Peruzzi F, Croul S, Khalili K, Reiss K: Insulin-like growth factor I receptor signaling system in JC virus $\mathbf{T}$ antigen-induced primitive neuroectodermal tumors - medulloblastomas. J Neurovirol 2002, 8(Suppl 2): |38-| 47.

165. Shimwell NJ, Martin A, Bruton RK, Blackford AN, Sedgwick GG, Gallimore $\mathrm{PH}$, Turnell AS, Grand RJ: Adenovirus 5 EIA is responsible for increased expression of insulin receptor substrate 4 in established adenovirus 5-transformed cell lines and interacts with IRS components activating the PI3 kinase/Akt signalling pathway. Oncogene 2009, 28(5):686-697.

166. Prisco M, Santini F, Baffa R, Liu M, Drakas R, Wu A, Baserga R: Nuclear translocation of insulin receptor substrate-I by the simian virus $40 \mathrm{~T}$ antigen and the activated type $\mathrm{I}$ insulin-like growth factor receptor. J Biol Chem 2002, 277(35):32078-32085.

167. Lassak A, Del Valle L, Peruzzi F, Wang JY, Enam S, Croul S, Khalili K, Reiss K: Insulin receptor substrate I translocation to the nucleus by the human JC virus T-antigen. J Biol Chem 2002, 277(19): $1723 \mid-17238$

168. Sun H, Tu X, Prisco M, Wu A, Casiburi I, Baserga R: Insulin-like growth factor I receptor signaling and nuclear translocation of insulin receptor substrates I and 2. Mol Endocrinol 2003, I 7(3):472-486.

169. Morelli C, Garofalo C, Sisci D, del Rincon S, Cascio S, Tu X, Vecchione A, Sauter ER, Miller WH Jr, Surmacz E: Nuclear insulin receptor substrate I interacts with estrogen receptor alpha at ERE promoters. Oncogene 2004, 23(45):7517-7526.

170. Wu A, Chen J, Baserga R: Nuclear insulin receptor substrate-I activates promoters of cell cycle progression genes. Oncogene 2008, 27(3):397-403.

17I. Chen J, Wu A, Sun H, Drakas R, Garofalo C, Cascio S, Surmacz E, Baserga R: Functional significance of type $I$ insulin-like growth factor-mediated nuclear translocation of the insulin receptor substrate-I and beta-catenin. I Biol Chem 2005, 280(33):299|2-29920.

172. Lanzino M, Garofalo C, Morelli C, Le Pera M, Casaburi I, McPhaul MJ, Surmacz E, Ando S, Sisci D: Insulin receptor substrate I modulates the transcriptional activity and the stability of androgen receptor in breast cancer cells. Breast Cancer Res Treat 2009, I I 5(2):297-306.

173. Tu X, Batta P, Innocent N, Prisco M, Casaburi I, Belletti B, Baserga R: Nuclear translocation of insulin receptor substrate- $I$ by oncogenes and Igf-I. Effect on ribosomal RNA synthesis. J Biol Chem 2002, 277(46):44357-44365

174. Trojanek J, Ho T, Del Valle L, Nowicki M, Wang JY, Lassak A, Peruzzi F, Khalili K, Skorski T, Reiss K: Role of the insulin-like growth factor I/insulin receptor substrate I axis in Rad5 I trafficking and DNA repair by homologous recombination. Mol Cell Biol 2003, 23(2I):7510-7524.

175. Trojanek J, Ho T, Croul S, Wang JY, Chintapalli J, Koptyra M, Giordano A, Khalili K, Reiss K: IRS- I-Rad5 I nuclear interaction sensitizes JCV T-antigen positive medulloblastoma cells to genotoxic treatment. Int $\int$ Cancer 2006, I I 9(3):539-548.

176. Urbanska K, Pannizzo P, Lassak A, Gualco E, Surmacz E, Croul S, Del Valle L, Khalili K, Reiss K: Estrogen receptor beta-mediated nuclear interaction between IRS-I and Rad5 I inhibits homologous recombination directed DNA repair in medulIoblastoma. J Cell Physiol 2009, 2 1 9(2):392-40 I.

177. Buck E, Eyzaguirre A, Rosenfeld-Franklin M, Thomson S, Mulvihill M, Barr S, Brown E, O'Connor M, Yao Y, Pachter J, Miglarese M, Epstein D, Iwata KK, Haley JD, Gibson NW, Ji QS: Feedback mechanisms promote cooperativity for small molecule inhibitors of epidermal and insulin-like growth factor receptors. Cancer Res 2008, 68(20):8322-8332.

178. Guix M, Faber AC, Wang SE, Olivares MG, Song Y, Qu S, Rinehart $C$ Seidel B, Yee D, Arteaga CL, Engelman JA: Acquired resistance to EGFR tyrosine kinase inhibitors in cancer cells is mediated by loss of IGF-binding proteins. I Clin Invest 2008, I I 8(7):2609-26|9. 